- improved cost effectiveness for new system development by reusing components;

- shortening man-hours by cutting down on recoding of repeating operations by reusing already defined components.

In author's opinion implementation of this method will increase efficiency SCADA in various fields.

This method could be used by system architects and programmers already working on existing SCADA reengineering projects.

Future reengineering model development will lay the ground for other support types of redesign SCADA. Reengineering SCADA will overcome the discrepancy between the pace of development of science and technology and design processes, improve technical support SCADA and reduce operating costs.

\title{
References
}

[1] E. M. Lavrischeva i V. N. Grischenko, Sborochnoe programmirovanie. Osnovyi industrii programmnyh produktov. K.: Nauk. dumka, 2009;

[2] S. S. Velykodniy, "Problema reinzhiniringa vidov obespecheniya sistem avtomatizirovannogo proektirovaniya," Upravlyayuschie sistemy i mashiny, no. 1, pp.57-61, 76, 2014;

[3] S. S. Velykodniy, "Reinzhiniring sistem monitoringu ta distantsiynogo upravlinnya sudnovimi energetichnimi ustanovkami," v Avtomatika 2015: Mater. XXII mizhn. konf. z avtom. upravl., Odesa, Ukraine, sent. 10 - 11, 2015 , Izd. Odesa: ONAFT, 2015, pp. 133-134;

[4] S. S. Velykodniy, "Metodologicheskie osnovy reinzhiniringa sistem avtomatizirovannogo proektirovaniya," Upravlyayuschie sistemy i mashiny, no. 2, pp.39-43, 2014;

[5] I. P. Norenkov, Osnovy avtomatizirovannogo proektirovaniya. M.: MGTU im. N. E. Baumana, 2009;

[6] A. A. Timchenko, Osnovi sistemnogo proektuvannya ta sistemnogo analizu skladnih ob'ektiv. Kn. 1. Osnovi SAPR ta sistemnogo proektuvannya. K.: LibId, 2000;

[7] A. A. Panteleymonov. “Aspekty reinzhenerii prilozheniy s graficheskim interfeysom polzovatelya,” Problemy programmirovaniya, no. 1-2, pp.53-62, 2001;

[8] M. Fauler, Refaktoring: uluchshenie sootvetstvuyuschego koda. SPb.: Simvol-Plyus, 2003.

\section{THE INTEGRATED LAYOUT DECISIONS FOR AUTOMATIC CONTROL OF PACKING SYSTEMS}

\author{
A. Volodin ${ }^{1}$, L. Kryvoplias-Volodina ${ }^{2}$ \\ ${ }^{1}$ National Technical University of Ukraine "Igor Sikorsky Kyiv Polytechnic Institute", Kiev, Ukraine \\ ${ }^{2}$ National University of Food Technologies, Kiev, Ukraine \\ ORCID: ${ }^{2} 0000-0001-9906-6381$ \\ Researcher ID : ${ }^{2} \mathrm{~L}-7826-2016$ \\ E-mail: ${ }^{1}$ sashavolodin4574741@ukr.net, ${ }^{2}$ krivoplyas-volodina@ukr.net
}

Copyright (C) 2014 by author and the journal "Automation technological and business - processes".

This work is licensed under the Creative Commons Attribution International License (CC BY).

http://creativecommons.org/licenses/by/4.0/

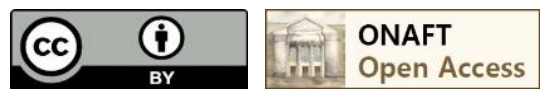

Abstract: On many industrial objects regulators of pressure are used. Following initial data are necessary for proper selection of a regulator and calculation of throughput: a working environment, entrance and target pressure, expense, temperature of a working environment, accuracy of regulation, a class of tightness, diameter of the pipeline, type of accession, constructional materials, external or internal registration of target pressure, protection against excess of pressure. 
The decision of this problem is closely connected with the proved choice of types of the process equipment, wide automation of technological processes, introduction of new technical decisions, use of necessary means of the control over realization of problems of complex mechanization of technological operations. In article the analysis of work of the functional module of a vertical multiline automatic packing machine on the basis of a proportional regulator of pressure "CAMOZZI» with realization of a feedback by means of an analog signal of regulator MX-PRO [1-3] is lead. The drive of the holder for a rolled material has been tested on proportional management of position of the directing rollers used on a technological site of supply and regulation of a tension of a tape of a roll of a packing material at formation of packing.

Results on use as the operating module of regulator MX-PRO for management of a drive of the holder for a roll of a material in view of a course and pressure in a pneumatic system are received. Carried out researches provide the way to raise operational properties of a transportation system of supply of a packing material for technological processes of packing modules at the food enterprises.

Аннотаџия: На многих производственных объектах используются регуляторы давления. Для правильного подбора регулятора и расчета пропускной способности необходимы следующие исходные данные: рабочая среда, входное и выходное давление, расход, температура рабочей среды, точность регулирования, класс герметичности, диаметр трубопровода, тип присоединения, конструкционные материалы, внешняя или внутренняя регистрация выходного давления, защита от превышения давления.

Решение этой проблемы тесно связано с обоснованным выбором видов технологического оборудования, иирокой автоматизацией технологических процессов, внедрением новых технических решений, использованием необходимых средств контроля для реализаџии задач комплексной механизации технологических операџий. В статье проведен анализ работь функичионального модуля вертикального многопоточного упаковочного автомата на базе пропорционального регулятора давления «Камоџции» с реализаџией обратной связи с помощью аналогового сигнала регулятора МX-PRO [1-3]. Привод рулонодержателя был протестирован на пропорциональное управление положением направляющих роликов, используемых на технологическом участке подачи и регулирования натяжения ленты рулона упаковочного материала при формировании упаковки.

Получены результаты по использованию в качестве управляющего модуля регулятора MX-PRO для управления приводом рулонодержателя с учетом хода и давления в пневмосистеме. Проведенные исследования дают возможность повысить эксплуатационные свойства транспортной системь подачи упаковочного материала для технологических прочессов упаковочных модулей на пищевых предприятиях.

Key words: Regulators, pressure, accuracy, roll, material, feedback.

Ключевые слова: Регуляторы, давление, точность, рулон, материал, обратная связь.

\section{Introduction}

The vertical multiline automatic packing machines working from two rolls, are applied usually to fine packing for portions of loose, liquid, viscous and fine piece production in flat packages for the packing, produced of various thermal welded or thermal stuck together film materials, as well as the filtrational paper laminated by polythene of a paper and an aluminium foil. Then opposite surfaces of such packages can be carried out from various materials.

For formation of a package it is necessary to provide regulation of pressure in system of a tension of rolled materials. To provide the process equipment with competitive characteristics allow electric mechatronic modules of positioning. In systems of hi-tech packing machines, at management of movement of functional working bodies, there is connected with variation of a configuration of working bodies a variation of inertial parameters of working links.

The model of system of positioning considered in the given work, allows not only to specify parameters of the functional module of a packing machine, and to change them by means of a feedback between a proportional regulator of pressure and the executive mechanism. For extension of works on research of applications of proportional regulators MX in systems of the automated pneumoelectric drive, research of application of such type of regulators has been executed. In control systems with a tension of a flexible material which is shaped in rolled structure, it is necessary to supervise a condition of supply of a material from a roll in a zone of formation of a package.

The analysis of existing decisions

In some cases operational and constructive characteristics are mutually connected and cannot be separated neatly from each other. The center of attention instead of separate components is the complex integrated solutions developed for a drive of mechanisms of the elevating equipment, for all technological processes of food branch, a robotics, manufacture of various packing machines, as well as a lot of other areas. They are a basis for successful and fast introduction of innovative development in the field of manufacture of cars and plants with objective of achievement more high efficiency. The productive and reliable equipment of company CAMOZZI is constructed on the recognized standards and differs convenience of service. For a condition of simple and flexible adaptation of separate functional modules and cars in a technological line of manufacture of packing, the possibility of fast readjustment of the equipment under new technological problems is. For motive power in electropneumatic systems compressed air is used. For adjustable supply of air it is carried out by reducers regulators of pressure, it is standard regulators of pressure which work on pressure decline on an output more often and have no possibility of fast readjustment during work on the removed control system. Regulators of set AR concern to such systems, AF (SMC), station of regulation of a feed of air type 708 (SAMSON), regulators of pressure MC (CAMOZZI) and other similar 
arrangements. The technology for coordinate regulation of a tension for tape was developed for digital press (polygraphic manufacture) all over again, but in the further has been recognized, that it is the excellent decision for packing machines with formation of packing from rolled materials, for example packing machines from Tetra Pak and Elopak.

To provide accuracy of overlapping of layers of a rolled material depends on two associated variables: tension of a tape and speed of its moving. In perfect conditions non-uniformity of a tension of a tape would not arise, and to adjust a tension it would not be required. For adjustment of a tension it is necessary in connection with influence of several factors: the fluctuations caused by mechanical discrepancies of a design; the various inertial response of mechanical elements during acceleration of a tape; non-uniformity in unwinding and a tension of rolls; slipping of fascinating rollers. CAMOZZI has developed systems for adjustment of supply of pressure of compressed air in system of a drive of a tension of a tape which is capable to solve the primary goal of rolled supply of materials, providing high speeds at high accuracy of overlapping. For synthesis and the analysis of work of packing machines with regulator CAMOZZI MX - PRO, as well as carrying out of the analysis of possible laws of supply of pressure in system of an electropneumodrive in the given work the special attention was given construction of mathematical model. For synthesis and the analysis of work of packing machines with regulator CAMOZZI MX - PRO, as well as carrying out of the analysis of possible laws of supply of pressure in system of an electropneumodrive in the given work the special attention was given construction of mathematical model.

Statement of a problem

The important problem at operation of systems of automatic control pressure of gas is maintenance of required dynamic quality and, first of all, absence of the uncontrollable self-oscillatory processes reducing service life of systems and accuracy of measurement of expense of gas [1]. In the scientific literature not enough attention has been given to studying of the factors influencing dynamic processes in system of regulators of pressure [2, 3].

Objective of work is the solution to the problem of optimum control by process of supply of a packing material and development of mathematical model of a regulator of pressure of compressed air in which the possibility of movement of elements of mobile system is considered from each other at movement between emphasises (pneumocylinders) of directing platens (fig.1).

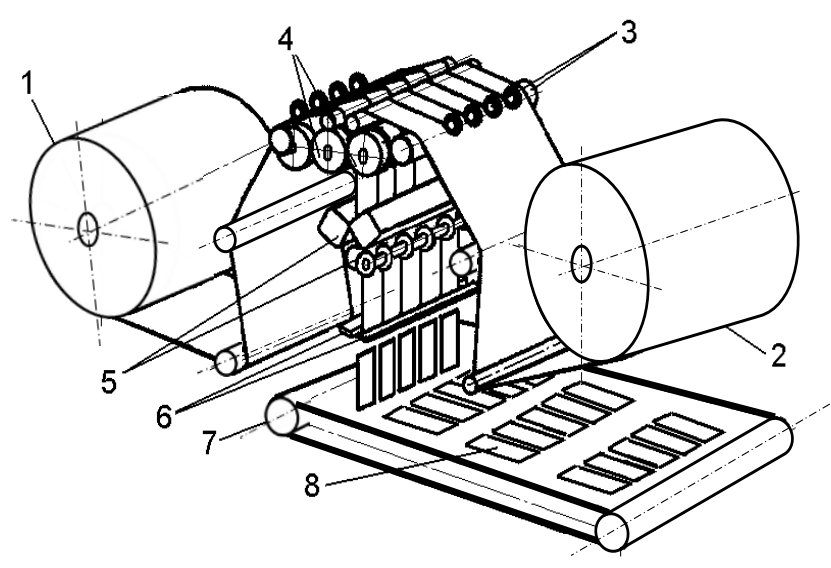

Fig. 1 - the Function chart of the vertical two-rolled multiline automatic device of model BAЭM 4/1-10/5

The regulator of pressure of gas is intended for maintenance of constant pressure on an input in a control system of directing and supporting platens. We shall consider application of a proportional regulator of pressure on the vertical multiline automatic device of model BАЭМ 4/10-10/5It consists of the arrangements of unwinding of rolls fixed on a bed 1 and 2 (fig.1.) a packing cloth; mechanisms 3 longitudinal are sharp rolled cloths on interfaced tapes; arrangements of the platen 4 step-by-step supplies of a packing material and formations of packages; the photogauge operating it reading from a surface of a tape special labels, defining length of packages; a multiline dosing out arrangement it (is not shown), packing up in shaped packages production for packing; the arrangement 5 welding edges of interfaced tapes by longitudinal seams; the arrangement 6 welding packages by a double cross-section seam with simultaneous operation of cutting of a material between seams; the marking arrangement blocked with it dating (6 figures) on a cross-section seam; the tape conveyor 7 driving from the automatic device ready packing units 8; as well as a case with an electric equipment and a microprocessor control system. The mathematical model of a regulator of pressure is described by the rated diagram of a regulator in working position, presented on fig. 2. At a conclusion for the system of the equations following assumptions have been accepted: a working body - ideal gas; heat exchange between gas and walls of a regulator is absent; the temperature of gas by a flowing part remains to a constant; transients of current of gas in throttles quasi-stationary. 


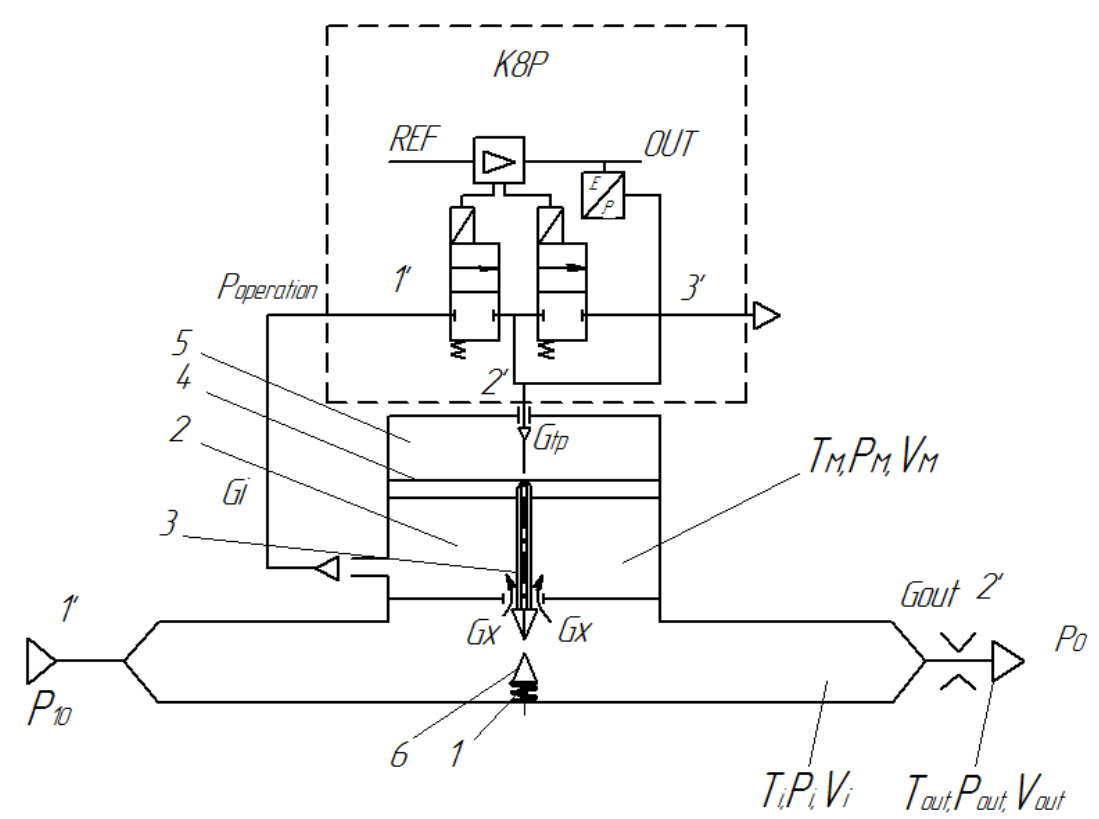

Fig. 2 - The generalized rated diagram of a regulator of pressure in view of the attached highways

The generalized rated diagram (fig.2) of a regulator of pressure in view of the attached highways, keeping constant pressure behind itself, made on an example of proportional regulators of pressure MX-PRO CAMOZZI is considered. During researches the proportional regulator of pressure on the basis of set MX in which instead of the handle with a spring the proportional regulator of pressure K8P adjusting pressure of management in the pilot chamber is established is considered. On fig. 2 pneumatic system with an electric proportional regulator of set K8P, consisting of the hollow rod 3 connected to a membrane 4 and piston in weight $\mathrm{m}$, as well as the piston 6 fixed on elastic communication by means of a rod and a gas spring 1 with rigidity $\mathrm{C} 1$. The chamber 2 , provides the way to support the installed pressure upon the main channel 1 ' -2 ' and to support a signal on pressure for the channel of a feedback with system of operating $2 / 2$ valves K8P on pressure. Pressure in the chamber 5 allows to operate a membrane 4 and to establish desirable pressure upon an output from a regulator. The channel 3 '-is the channel of an exhaust at dump air. [3]. The piston 3 and a membrane are under action of command pressure Poperftion from operating valves K8R - specifying. The equation of balance of a membrane as dynamic link with the concentrated parameters $\mathrm{m}, \mathrm{Cпр}, \xi$ - is presented in the form of:

$$
m \frac{d^{2} x}{d t^{2}}+\xi \frac{d x}{d t}+C_{n p} x-F_{01}+F_{02}-F_{\Sigma}=0
$$

where $F_{\Sigma}$ - the sum of forces of nonlinear friction, aerodynamic elevating force and the forces acting on a membrane and a rod; $C_{n p}$ - rigidity of a spring, $\mathrm{N} / \mathrm{m} ; \mathrm{m}$ - weight of mobile system, $\mathrm{kg}$; $\xi$-damping; $F_{01}, F_{02}$ - efforts of preliminary influence of a mechanical spring 1 (fig.1) and a gas spring in the chamber 5. By assumption in mathematical model also it has been taken: insignificant influence of forces of friction and elevating force of a stream on static and dynamic characteristics of system:

$F_{\Sigma}=-p_{m} S_{m}+p_{i} S_{c}-p_{10} S_{T}+p_{a} S_{m}$, when $p_{m}$ - pressure in a cavity under a membrane; $S_{m}-$ the area of a membrane; $p_{a}$ - atmospheric pressure; $S_{c}$ - the area of a saddle of the valve; $S_{T}$ - the area of a plate where $\mu_{i}-$ factor of expense; $x-$ course of a membrane of the valve; $R$ - gas constant; $T_{i}$ - temperature of braking; $k$ - parameter of an adiabatic curve; $p_{i}-$ absolute pressure; $S_{i}$ - the area of through passage section; $\pi_{\kappa p}-$ the critical attitude of pressure. 


$$
\begin{aligned}
& \int_{c} \cdot \frac{d P_{c}}{d t}=G_{i+1}-G_{\text {out }}, \\
& \left|G_{x}=\mu_{x} \pi d_{c} x P_{10} \sqrt{\left.\frac{2}{R T_{10}} \frac{k}{k-1} !\left(\frac{P_{1}^{\prime}}{P_{10}}\right)^{\frac{2}{k}}-\left(\frac{P_{1}^{\prime}}{P_{10}}\right)^{\frac{k+1}{k}}\right\}}\right| \text {, при } \frac{P_{1}^{\prime}}{P_{10}}>\pi_{k p} \text {, } \\
& G_{x}=\mu_{x} \pi d_{c} x P_{10} \sqrt{\frac{k}{R T_{10}}}\left(\frac{2}{k+1}\right)^{\frac{k+1}{2(k-1)}}, \text { npu } \frac{P_{i}}{P_{10}} \leq \pi_{k p}, \\
& \left\{G_{i}=\mu_{i} S_{i} p_{i} \sqrt{\left.\frac{2}{R T_{i}} \frac{k}{k-1} !\left(\frac{p_{i+1}}{p_{i}}\right)^{\frac{2}{k}}-\left(\frac{p_{i+1}}{p_{i}}\right)^{\frac{k+1}{k}}\right\}} \text {, при } \frac{p_{i+1}}{p_{i}}>\pi_{k p},\right. \\
& G_{i}=\mu_{i} \pi S_{i} P_{i} \sqrt{\frac{k}{R T_{i}}}\left(\frac{2}{k+1}\right)^{\frac{k+1}{2(k-1)}}, n p u \frac{P_{i}}{P_{10}} \leq \pi_{k p}, \\
& m \frac{d^{2} x}{d t^{2}}+D \frac{d x}{d t}+C_{n p} x-F_{01}+F_{02}-F_{\Sigma}=0, \\
& F_{\Sigma}=-p_{m} S_{m}+p_{i} S_{c}-p_{10} S_{T}+p_{a} S_{m} \text {, } \\
& m \frac{d^{2} x}{d t^{2}}+\xi \frac{d x}{d t}+C_{n p} x-p_{01}+p_{02}+p_{m} S_{m}-p_{i} S_{c}+p_{10} S_{p}+p_{a} S_{m}=0
\end{aligned}
$$

In rated model following assumptions [2] are accepted: a working body - ideal gas; pressure and temperature upon an input of a regulator are constant, i.e. $\mathrm{P} 0=$ const, $\mathrm{T} 0=$ const; Mode of flowing of gas in a cavity of the consumer - critical; heat exchange between gas and walls of a design is absent.

Believing, that the condition of gas in a cavity changes under the adiabatic law, it is possible to record (2): гд when $\mu_{x}-$ factor of expense in section of a rod 3 (fig.1); $d_{c}$ - diameter of the piston on a rod 3; $\mathrm{x}$ - course of a plate of the valve; $\mathrm{R}-$ gas constant; $\mathrm{T}_{10}$ - temperature of braking in the chamber $2 ; \mathrm{k}$ - parameter of an adiabatic curve; $\mathrm{Pi}$ - pressure before an input in K8P; $\mathrm{P}_{10}$ - pressure upon an input in a regulator of pressure; $\pi_{k p}$ - the critical attitude of pressure, $P_{c}-$ pressure in a cavity of the chamber $2 ; G_{i+1}$ - the mass expense defined by operating valves K8P; $V_{c}$ - volume of a cavity of the chamber 2 ; $G_{i}-$ mass expense feeding $\mathrm{K} 8 \mathrm{P} ; \mathrm{R}$ - gas constant; $\mathrm{k}$ - parameter of an adiabatic curve; $T_{c}$ - temperature of gas in a cavity; $C_{c} .-$ Capacity of variation of pressure (rigidity of a gas spring). The method of carrying out of experiment consist in supervising working pressure in the set intervals by means of a regulator of pressure. In parallel with experimental researches the analytical model constructed in view of the generalized equation of conservation of energy was analyzed. Readings of regulation on pressure are removed in system Fluid Lab-PA, through EasyPort for maintenance of communication between the personal computer and MX-PRO. For removal of the characteristic of a regulator and definition of reaction to individual influence such functions, as a choice of channels of measurement, correction of time of measurement or the analysis by means of the cursor with function of scaling were used.

\section{Conclusion}

The received system of the equations (2) describes functioning a regulator of pressure of gas with the attached capacity and a package of operating elements. At the set expense of gas through a regulator and required value of pressure on output Pout (fig.2) on its mobile parts the balance of forces is established. At variation of expense of gas through a regulator, for example, an increase due to the consumer, pressure upon its output Pout will decrease, owing to what the balance of forces on a sensitive element of a regulator - the piston that will lead to an increase of the area of section of a throttle between the piston 6 and the piston of a rod 3 will be broken. Pressure upon an output increases up to required Pout and occurs restoration of balance of forces on mobile parts of a regulator. At reduction of expense through a regulator regulation of pressure on an output occurs similarly. According to the accepted assumptions the equations describing gas dynamic processes in a regulator of pressure of gas are received, losses of energy are considered by means of factor of expense. By means of modelling behaviour of a working environment (fig.3), in a regulator and on an output from it, probably to estimate size of speed of system during test, possible deviations from the installed ranges of adjustable sizes and to reach stable position of working processes in the mechanical systems operated by means of regulators. MX-PRO it was used for maintenance of constant pressure on an input in a control system of directing and supporting platens, provides the way to provide the technological control over operation in a mode of actual time. 
a)
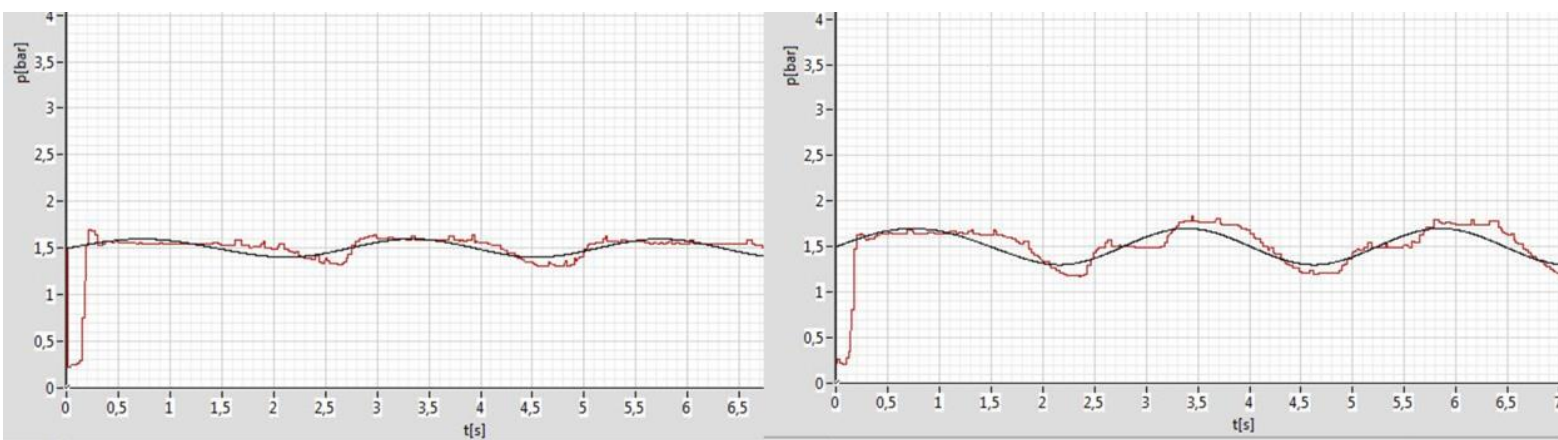

b)
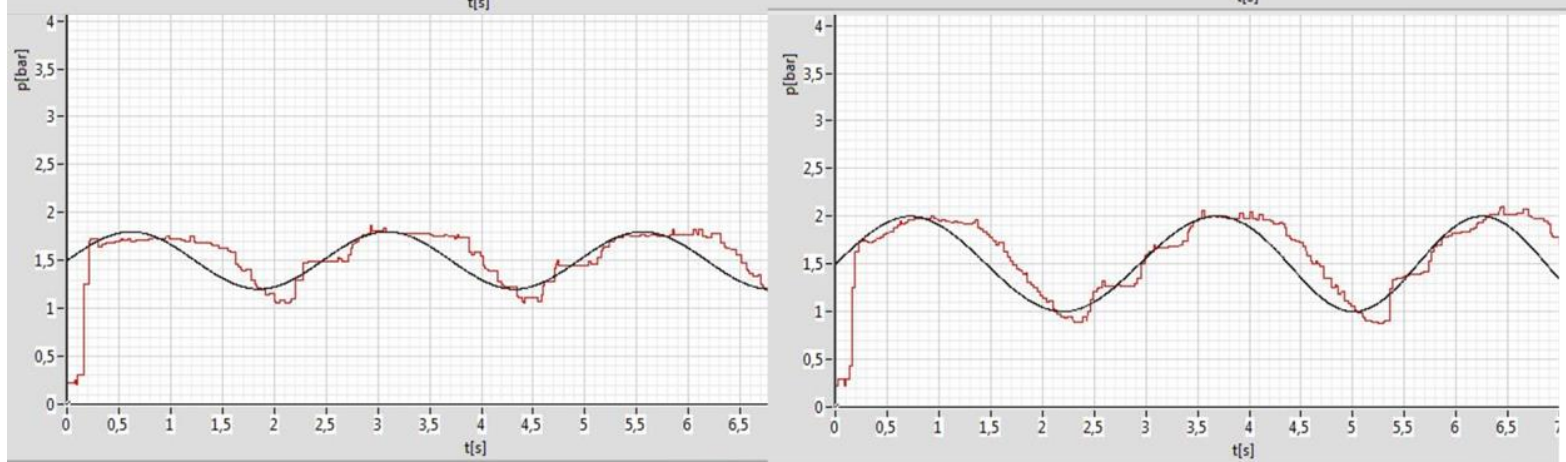

Fig. 3 - Results of calculations and measurements of pressure on an output at use of different operated volumes: a) $\mathrm{V}=$ $0.1 \mathrm{m3}$, b) $\mathrm{V}=0.2 \mathrm{m3}$.

\section{References}

[1] Tehnichni informatsiyni resursi. [Elektronniy resurs] : [Veb-sayt]. - Elektronni dani. - Kiyiv: CAMOZZI. - Rezhim dostupu do katalogu.: http://catalog.camozzi.ua - Nazva z ekranu.

[2] V. G. Shipinskiy, Osnovyi poligrafii i dekorirovaniya upakovki: kurs lektsiy dlya studentov spetsialnosti I-38 2002 «Upakovochnoe proizvodstvo». Gomel: GGTU im. P. O. Suhogo, 2008;

[3] B. Dawson (2012, Feb. 25). “Comparing floating point numbers," www.cygnussoftware.com. [Online]. Available: http://www.cygnussoftware.com/papers/comparingfloats/comparingfloats.htm. [Accessed: Feb. 27, 2012].

\section{Література}

[1] Технічні інформаційні ресурси. [Електронний ресурс] : [Веб-сайт]. - Електронні дані. - Київ :CAMOZZI. Режим доступу до каталогу.: http://catalog.camozzi.ua — Назва з екрану.

[2] В. Г. Шипинский. Основы полиграфии и декорирования упаковки: курс лекций для студентов специальности I382002 «паковочное производство». Гомель: ГГТУ, 2008;

[3] Б. Доусон (2012, лютого 25). “Comparing floating point numbers, ” www.cygnussoftware.com. [Онлайн]. Доступно: http://www.cygnussoftware.com/papers/comparingfloats/comparingfloats.htm. [Доступно: Лютого 27, 2012]. 


\title{
OPTIMIZATION OF THE COMPOSITION OF MUFFINS ON THE BASIS OF ESSENTIAL INDICATORS OF CHEMICAL COMPOUND OF THE CONFECTIONARY PRODUCT "VUPI PAI"
}

\author{
A. Antonova ${ }^{1}$, N. Dzyuba ${ }^{2}$ \\ ${ }^{1}$ Odessa National Academy of food technologies, Odessa \\ ORCID: 0000-0003-3599-0983 \\ E-mail: ${ }^{1}$ allaantonova62@gmail.com
}

Copyright (C 2014 by author and the journal "Automation technological and business - processes". This work is licensed under the Creative Commons Attribution International License (CC BY). http://creativecommons.org/licenses/by/4.0/

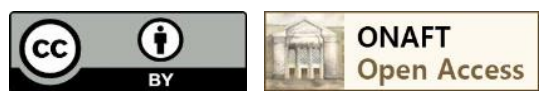

Abstract: The article is concerned with the analysis of recipes of confectionary products on the basis of essential indicators of chemical composition meeting the demands of definite group of consumers (corresponding the physiological norms of feeding the different group of population). The ratio of carbohydrates and proteins which is determined for correlating group of the intensity of labour is analized. Criteria of optimality of the composition of present products were adopted on this basis. The received results give the possibility of choice of the composition of farinaceous confectionary product concidering the aminoacid composition. Variants of the optimized recipes of the farinaceous confectionary product enriched with gluten were obtained. Key indicators of quality of the made farinaceous confectionary product were defined.

Key words: Objective function, optimization criteria, chemical composition, physiological standart, gluten, aminoacid, recipes.

\section{Introduction}

In recent years the government pays great attention to new approaches to solve environmental and food problems. These issues are of great socio-economic importance to the population, estimating the potential of technological development and health.

Global environment pollution almost reached critical level in water, air, medicinal herbs, food. In particular, harmful to human health products accumulate in soil and food, which reduces their usefulness and changes the chemical composition, may change the potential gene fund and cause unexpected mutations.

Scientific and technical bases of products production of popular, children, preventive, medicinal and special food is developed by scientists and has sufficient theoretical and applied levels. Scientists have suggested the technologies arranged for the protection of the health with the use of new elements of structure possessing both technological and physiological properties. They have aptitude to form a proper structure of the food and remove from it agents which are not recommended by medical demands and maintain competition ability of a producer. Today the production of health protective food is competitive factor for the development of restaurant business.

It is well known that the state of protein metabolism in humans largely depends of lack or absence of essential amino acids. High functional qualities of animal proteins occur in their water-holding capacity.

Functional and technical qualities of animal protein (water-retaining, emulsifying ability, thermal stability, etc.) permit to use them for different target areas [1,2].

The use of animal protein material allows collagen keeping stuff to enrich products with detoxicants, and significantly improve the rheological quality and consistency of food. In order to assimilate collagen its hydrolysis is carried out [3].

Formulation of the problem

The goal of the search is to optimize recipes for muffins according to the main indicators of chemical composition, to meet the needs of a particular group of consumers (under physiological nutrition standards for different groups).

According to this goal optimality criterion has been defined. As an optimality criterion or objective function of the mathematical model we selected ratio of carbohydrates and proteins, which is set for a proper group of work intensity [4]. 